\title{
Organizations, Learning, and Sustainability: A Cross-Disciplinary Review and Research Agenda
}

\author{
Melanie Feeney ${ }^{1} \cdot$ Therese Grohnert $^{1} \cdot$ Wim Gijselaers $^{1} \cdot$ Pim Martens ${ }^{1}$
}

Received: 7 December 2020 / Accepted: 8 February 2022 / Published online: 23 February 2022

(c) The Author(s) 2022

\begin{abstract}
This paper explores the role of learning in organizational responses to sustainability. Finding meaningful solutions to sustainability challenges requires companies and other actors to broaden their thinking, go beyond organizational boundaries and engage more with their stakeholders. However, broadening organizational perspective and collaborating with diverse stakeholders involves inherent political and process-related tensions. Learning has been identified as a key organizing process for overcoming the challenges that arise through collaborative action for sustainability. In order to understand the role of learning in organizational responses to sustainability, we conduct a cross-disciplinary systematic review of the literature on learning for sustainability and incorporate perspectives from diverse disciplines including business, management, environmental science, sociology, policy, urban planning, and development. The review explores how different disciplines conceptualize and operationalize learning for sustainability and identifies the common themes and challenges. Our findings highlight the different ways that power relations influence learning and decision-making processes, and how entrenched traditional value structures and 'reflexive complicity' limit practitioners and researchers alike in finding meaningful sustainability solutions. We conclude that shifting how we motivate business and management research on learning for sustainability, in a way that prioritizes sustainability outcomes over firm performance, could bring us a step closer to more meaningful responses to sustainability. Similarly, breaking patterns of 'reflexive complicity' by key actors in business could assist in shifting toward more radical and long-term responses to sustainability in practice.
\end{abstract}

Keywords Sustainability $\cdot$ Learning $\&$ development $\cdot$ Multi-stakeholder initiatives

\section{Introduction}

Effects of climate change are being observed at an increasingly alarming rate across the world. Each year we see more severe flooding, droughts, bushfires and heatwaves, and recent studies show that unless we change our current practices these events will continue to worsen (Intergovernmental Panel Climate Change, 2018). Finding meaningful

Melanie Feeney

melanie.feeney@maastrichtuniversity.nl

Therese Grohnert

t.grohnert@maastrichtuniversity.nl

Wim Gijselaers

w.gijselaers@maastrichtuniversity.nl

Pim Martens

p.martens@maastrichtuniversity.nl

1 The University of Maastricht, Tongersestraat 53, 6211LM Maastricht, The Netherlands solutions to sustainability challenges requires companies and other actors to broaden their thinking, go beyond organizational boundaries and engage more with their stakeholders (De Bakker et al., 2019; Williams et al., 2017). However, broadening organizational perspectives and collaborating with diverse stakeholders involves inherent political and process-related tensions stemming from a resistance to change, competing motivations, lack of trust, and disciplinary-specific language (Bechky, 2003; Edmondson \& Nembhard, 2009; Roux et al., 2017). Learning has been identified as a key organizing process for overcoming the challenges that arise in collaborative action for sustainability (Oelze et al., 2016; Osagie et al., 2020; Roux et al., 2017). Improving an organization's ability to learn has been directly linked to their ability to adapt and change (Edmondson \& Moingeon, 1998; Edmondson \& Nembhard, 2009); both of which are necessary for organizations responding to sustainability (Linnenluecke et al., 2009). While there are a variety of definitions of learning used across the literature (e.g., Argyris 
\& Schon, 1996; Crossan et al., 1999; Laasch \& Gherardi, 2019), this review adopts Probst and Büchel's (1997) definition of learning as when an individual or organization's "knowledge and value base changes, leading to improved problem-solving ability and capacity for action" (p.15). In this article, we are therefore interested in how organizations from diverse sectors engage in learning for sustainability, and how insights from current research can benefit future business and management research.

Sustainability challenges are complex and chaotic problems with no clear solution or disciplinary boundary and thus require novel forms of organizing and collaborating (Snowden \& Boone, 2007; Williams et al., 2017; Wright \& Nyberg, 2017). Traditional responses to sustainability have largely focused on government regulation and taxation of the private sector (Brønn \& Vidaver-Cohen, 2009; Sharma \& Ruud, 2003), and investment in sustainable innovations, voluntary reporting and private regulation of corporate conduct by the private sector (De Bakker et al., 2019; Schaltegger \& Wagner, 2011). Despite these attempts by government and business, progress toward sustainability is slow and we continue to see a tendency of actors operating in their disciplinary silos (Laasch et al., 2020).The Intergovernmental Panel on Climate Change (IPCC) (2018) and the United Nation's Sustainable Development Goals (SDGs) framework both stress the need for multi-level and cross-sectoral mitigation and adaptation strategies to achieve progress toward sustainable development (Scheyvens et al., 2016; United Nations, 2019). However, collaboration with diverse stakeholders is no easy task, as each stakeholder comes with their own, often conflicting, interests for engaging in sustainability collaborations (Hörisch et al., 2014).

Learning has been identified as a key process for enabling organizations to collaborate and respond to sustainability. Firstly, learning processes such as open dialogue, reflection, shared visions and goals, and creating environments of trust can all contribute to more effective collaborations among diverse actors (Edmondson \& Moingeon, 1998; Freeth \& Caniglia, 2020). Secondly, knowledge acquisition has been identified as key for (1) adopting more sustainable practices, and (2) increasing awareness of other pressing sustainability issues within the organization's control (Hörisch et al., 2014). Learning is therefore not proposed here as an alternative to traditional responses, such as regulation or technological advancement, but rather as a key organizing process for improving the capacity of individuals, teams, organizations, and networks to achieve their sustainability goals.

Studies in business and management have explored the importance of learning for engaging individuals and organizations in the implementation of corporate social responsibility (CSR), and other sustainability initiatives (Haugh \& Talwar, 2010; Oelze et al., 2016; Prugsamatz, 2010; Siebenhüner \& Arnold, 2007). In the environment, social sciences and policy disciplines learning has also been explored for its role in enhancing the collaborative and adaptive capacity of inter-organizational responses to sustainability (Barth \& Michelsen, 2013; Rumore et al., 2016). Although there are similarities in how each discipline defines and values learning for sustainability, a lot remains unknown about how each discipline conceptualizes and operationalizes learning within the context of sustainability. We therefore conduct a cross-disciplinary systematic review of the literature to better understand the role of learning for sustainability.

This review builds on recent reviews within the business and management literature that have explored organizational learning and CSR (Fortis et al., 2018), responsible management learning and competences for corporate sustainability (Cullen, 2020; Dzhengiz \& Niesten, 2020; Laasch et al., 2020; Montiel et al., 2020), and multi-stakeholder initiatives for sustainability (De Bakker et al., 2019). Despite the emergence of review studies on learning for sustainability within the business and management discipline, there is currently a lack of understanding about how the process of learning for sustainability is conceptualized and organized across different academic disciplines. To overcome this gap, this review moves beyond a siloed approach to reviewing the literature on learning for sustainability from individual disciplines and incorporates perspectives from diverse disciplines including business, ethics, management, human resource development (HRD), environmental science, public administration, political science, health, engineering, agriculture, and development studies. The review is guided by the following research question and subquestions:

How does learning help to achieve sustainability?

- How do different disciplines conceptualize and organize learning for sustainability?

- What are the key barriers and enablers of learning for sustainability across disciplines?

- What does this mean for future business and management research and practice?

Through applying a cross-disciplinary review methodology, our paper synthesizes a broad body of research spread across academic disciplines and offers a comprehensive review of learning for sustainability. By identifying what we know and what is still to be understood about learning for sustainability across disciplines, we show in what ways business and management scholars can contribute to future academic debate. In doing so, our paper also contributes to developing shared understandings of the complexity of achieving sustainability across disciplines and thus places business and management scholars in a better position to engage in meaningful transdisciplinary research projects for sustainability. Similarly, our paper deepens understanding of organizing for sustainability in practice. Through identifying 
the challenges and enablers of learning across different sectors and organizations, our findings provide key insights for leadership seeking to achieve sustainability outcomes within their organization and broader networks.

The review is organized as follows; first we introduce the theoretical elements that are central to learning for sustainability and guide our methodology. We then present our findings on the central areas of learning for sustainability that are addressed across all disciplines and identify the critical areas that differ across fields. We highlight key areas for future business and management research and the implications for practice, before presenting the studies' limitations and concluding remarks.

\section{Definitions and Relevance of Learning for Sustainability in Organizations}

\section{Defining Sustainable Development and Learning}

The terms 'sustainability' and 'sustainable development' are often used interchangeably; however, there are clear distinctions between the two (Salas-Zapata \& Ortiz-Muñoz, 2019). The United Nations Educational, Scientific and Cultural Organization (UNESCO, 2019) state that "sustainability is often thought of as a long-term goal (i.e., a more sustainable world), while sustainable development refers to the many processes and pathways to achieve it (i.e., sustainable agriculture and forestry...education and training, etc.)" (p. 3 ). In this paper, we mainly use the term 'sustainability' as we are interested in what factors contribute to long-term sustainability goals and outcomes. However, as our review focuses on the process of learning as a pathway for meeting sustainability goals and outcomes, we explore the concept of 'sustainable development' in greater detail below.

Sustainable development was defined in the United Nations 1987 Brundtland report as meeting "the needs of the present without compromising the ability of future generations to meet their needs" (p. 43). Many scholars have since argued that this definition is too human-centric and fails to capture the complexity of humanity's relationship with nature (Hopwood et al., 2005; Salas-Zapata \& Ortiz-Muñoz, 2019). More recent sustainable development research builds upon Rockström et al.'s (2009a) 'Planetary Boundaries Framework for Human Development' that identified 'a safe operating space for humanity' based on nine environmental thresholds. The framework challenges previous assumptions of economic growth by acknowledging that human development is not possible if certain environmental needs are not met. In 2015, the United Nation's General Assembly officially launched their 17 interconnected Sustainable Development Goals (SDGs) that were proposed as a social and ecological blueprint for humanity's journey to 2030
(United Nations, 2016). The goals were widely celebrated by the international community for their ambitious targets "to end poverty and hunger everywhere; to combat inequalities within and among countries; to build peaceful, just and inclusive societies; to protect human rights and promote gender equality and the empowerment of women and girls; and to ensure the lasting protection of the planet and its natural resources" by 2030 (United Nations, 2016, p. 3). However, the SDGs have also been met with some criticism. Raworth (2014), argues that while the SDGs do provide much to celebrate, they lean too heavily toward the social elements of sustainability, and in their current form, would not ensure that we stay within Rockström et al.'s (2009a, 2009b) nine environmental thresholds.

Raworth's (2017) 'Doughnut of Social and Planetary Boundaries' framework arguably strikes a better balance between the social and ecological elements of sustainability. Building on Rockström et al.'s nine environmental boundaries, Raworth's 'doughnut' introduces twelve social foundations, for example health, education, income and work, and peace and justice. Raworth (2017) draws attention to the minimum social standards that should be met when pursuing sustainability and rejects the notion of endless growth that places us under threat of exceeding the environmental thresholds of the planet. Raworth's definition, "a future that can provide for every person's needs while safeguarding the living world on which we all depend" (2017, p.39), instead emphasizes the need to 'thrive in balance,' acknowledging that all economic and societal activities must exist within the Earth's natural planetary boundaries.

While there are differences in their approaches, the argument Rockström et al. (2009a, 2009b), the United Nations General Assembly (2016) and Raworth (2017) all have in common is that our current structures, norms, beliefs, and ways of operating are unsustainable. In order to be truly sustainable, we must understand the interconnectedness of the systems that we live within and challenge our underlying assumptions about what we value and how we organize as a civilization. Such a drastic shift in how we understand and organize our natural resources, societies and economy requires changes in our beliefs, values and structures (Hueting, 2010). In other words, we need to learn to think and act in different and more sustainable ways. This paper adopts Probst and Büchel's (1997) definition of learning, defined in the introduction, as it is not specific to any one discipline, thus fitting with the interdisciplinary nature of our review. It also emphasizes the importance of learning not just for knowledge acquisition but for stimulating changes in values and behaviors. Learning, as a vehicle for changing values and behavior, is therefore a key ingredient for achieving the type of meaningful sustainability outcomes called for by Rockström et al. (2009a), the United Nations (2016), and Raworth (2017). However, most research on learning 
for sustainability is in the context of schools and universities (e.g., Muff, 2012; Sharma \& Hart, 2014), with limited understanding of how learning for sustainability occurs in organizational settings.

\section{Learning for Sustainability in Organizations}

There is the common misconception that learning only occurs in settings like schools and universities; however, learning also occurs in workplaces, through social interactions, and lived experiences (Jeong et al., 2018; Lam, 2000). Learning is both a process that unfolds over time, i.e., enrolling in a training program, and an outcome of gaining insights from prior actions, i.e., reflecting on past projects (Rashman et al., 2009). This study focuses on learning that occurs outside of formal education systems as organizations play an important role in achieving sustainable development (Bansal, 2003; Battilana \& Dorado, 2010). For example, corporations are predominantly responsible for the world's global $\mathrm{CO}_{2}$ emissions. Governments, NGO's and other societal actors are largely responsible for holding corporations accountable for this (Brønn \& Vidaver-Cohen, 2009; Nyberg \& Wright, 2016; Sharma \& Ruud, 2003). Understanding the role of learning for facilitating sustainability actions from the above organizations therefore has the potential to greatly impact future sustainable development efforts.

To understand the role of learning for sustainability, we need to appreciate that learning occurs at and across the individual level (Edmondson \& Moingeon, 1998), team level (Koeslag-Kreunen et al., 2018), organizational level (Bechky, 2003), and inter-organizational and network levels (Rashman et al., 2009). While many researchers consider multi-stakeholder and inter-organizational learning as key for tackling complex sustainability challenges, this cannot happen without engaged individuals (Barth \& Michelsen, 2013; Siebenhüner \& Arnold, 2007), teams (Molnar \& Mulvihill, 2003), and organizations that embed their new knowledge into daily processes, practices, and values (Senge $\&$ Carstedt, 2001).

At the individual level, learning is an essential first step for adopting more sustainable organizational practices as it facilitates new knowledge and expertise of sustainability issues that can then be shared from the individual to the organization (Camps \& Majocchi, 2010; Prugsamatz, 2010). Individuals also play an important role in the effectiveness of team learning through adopting attitudes and behaviors that facilitate learning such as adaptability and openness to learning and change processes (Kozlowski \& Chao, 2012). At the team level, learning allows for groups to grasp complex sustainability concepts and share skills, expertise and knowledge to tackle specific sustainability challenges (Molnar \& Mulvihill, 2003; Senge \& Carstedt, 2001). Finally, through having a combination of knowledgeable, adaptive and engaged individuals and teams, organizations are better prepared to embed sustainability policies, processes, and values throughout their organization and networks (Bell et al., 2012; Teare, 1997). This paper therefore draws on four levels of analysis when looking at learning for sustainability: individual, team, organization, and inter-organizational networks.

Many of the elements identified as important for learning in organizations are also important for sustainable development, as both organizational learning and sustainability require "a challenge to mental models, fostering fundamental change, engaging in extensive collaborative activity and, in some cases, revisiting core assumptions about business and its purpose" (Molnar \& Mulvihill, 2003, p. 168). As a result, many business and management scholars have sought to understand the relationship between learning in organizations and sustainability. Learning for sustainability in organizations has been studied from a variety of lenses. Management scholars have explored the learning processes that facilitate company sustainability outcomes and performance (e.g., Oelze et al., 2016; Wicki \& Hansen, 2019), the experiences and challenges of companies engaging in learning for sustainability (e.g., Molnar \& Mulvihill, 2003), and the internal and external drivers that influence sustainability learning processes (e.g., Müller \& Slominsky, 2017).

One recent review paper looked specifically at the role of organizational learning in the context of CSR (Fortis et al., 2018). The authors proposed a conceptual framework that captured the macro-level learning processes that contribute to CSR development, including sources, processes, and outcomes of CSR learning. While insightful for business and management scholars, the authors highlight the need to go beyond disciplinary silos and encourage researchers in interconnected disciplines "to learn from each other by sharing knowledge, definitions, and methodological approaches that have been already tested within their respective areas regarding the OL (organizational learning) process" (Fortis et al. p. 294). Heeding this call, our paper extends knowledge of learning for sustainability within the business and management literature by drawing on insights from broader disciplines.

The concept of learning for sustainability is certainly not limited to business and management literature; many other disciplines have also acknowledged its importance. In the environmental sciences, there is an abundance of literature on the organized learning processes of natural resource management projects (e.g., Wossen et al., 2013) or in responding to changing climate conditions (e.g., Madsen et al., 2019). In development and planning studies, research has explored collaborative learning approaches for building resilient municipalities and cities (e.g., Storbjörk, 2010). Similarly, in agricultural studies, researchers have looked at the importance of learning in the uptake of sustainable 
farming practices (e.g., Kiptot \& Franzel, 2019). Finally, the political sciences and transition management literature acknowledges learning processes as key for moving toward sustainable development (Kemp et al., 2007). Within these diverse literature streams are key insights into the processes, barriers and enablers of learning for sustainability that are relevant to business and management research and practice. This paper will analyze the conceptualization and operationalization of learning for sustainability from diverse disciplinary perspectives both within and beyond the field of business and management, to develop clear avenues of future business and management research.

\section{Methods}

\section{Literature Search Procedure}

The present review follows Petticrew and Roberts's (2006) five-step method for executing systematic reviews in the social sciences. First, formulate the research questions, second define the search terms and the database(s) to be used, third identify inclusion and exclusion criteria, fourth evaluate the scientific quality of the selected articles using predefined quality criteria, and fifth analyze each paper in depth to answer the research questions.

\section{Database and Literature Search Terms}

We used the Web of Science scientific database offering a rich source of over 34,385 journals, books, proceedings, patents, and data sets from across multiple disciplines (Web of Science Group, 2019). Several search term combinations were used. We started with the term "sustainability" and developed several synonyms for sustainability to capture similar terms commonly used across disciplines, including "green human resource*," "CSR," "climate change," "creating shared value," "circular economy," and "SDGs." To obtain articles that focus on learning at multiple levels across organizations, we used each of the above terms in combination with the following learning terms, "individual learning," "professional learning," "employee learning," "staff learning," "team learning," "group learning," "organizational learning," "cross-boundary learning," "network learning," "collaborative learning," and "Human Resource Development AND Training."

Following previous literature reviews, the inclusion criteria focused only on articles published in scientific peerreviewed journals and included 'online first' and 'pre-publication' articles. All other scientific publications, including books, book chapters, and conference proceedings were excluded. The search included articles published from 1993 as this was the year after the milestone Rio Earth Summit where global actors committed to a comprehensive action plan on the environment, society, and development. Data collection concluded on May 1, 2020. Articles had to be published in English with a full-text version available. Our search strategy resulted in 1565 publications.

\section{Selection Process}

The titles, abstracts, and when necessary, the methods section of all publications obtained from the search terms described above were read and the following exclusion criteria were applied:

1. Only articles that used learning in the context of sustainability, as defined above by the authors, were included.

2. Only articles that referred to learning from a work or business perspective were included. This included individual learning that took place within an organization and learning that took place as part of an organized network of people.

3. Only theoretical and empirical articles were considered. All other papers including opinion and review articles were excluded.

4. Only articles where learning was a focus of the study were included. Articles where learning was only a finding of the study, e.g., by formulating lessons learned, were excluded.

After applying the inclusion and exclusion criteria, 114 articles were selected for further analysis. While reviewing the full-text versions of the remaining articles against the above inclusion criteria, a quality check was also applied to evaluate the scientific quality of the empirical studies described (Gast et al., 2017). The quality of articles was checked using the 11-Point quality criteria detailed in Table 1, drawn from Petticrew and Roberts (2006). Each criterion was evaluated on a 3-point scale: $0,0.5$, or 1 point. For articles to be included in the review, they had to have a score of at least 9 across the 11 criteria. After this quality check, 105 articles remained that were eligible for inclusion; 9 articles did not meet the 11-Point quality criteria. Figure 1 outlines the process and records the number of articles at each stage of the search process.

\section{Analysis}

The 105 articles were read in-depth by the first author and analyzed using a combination of deductive and inductive coding methods. As it was a cross-disciplinary review study, the data analysis started by identifying the journal and discipline of each article. Disciplinary categories were determined by searching for the Journal via the Web of Science Journal Citation Reports. Articles were coded for the 
Table 1 11- Point quality criteria

\begin{tabular}{|c|c|}
\hline Category & Quality criteria \\
\hline \multirow[t]{2}{*}{ General } & 1. Is the research objective clear? \\
\hline & 2. Is the chosen method capable of finding a clear answer to the research question? \\
\hline \multirow[t]{2}{*}{ Selection sample } & 3. Were enough data gathered to assure the validity of the conclusions? \\
\hline & 4. Is the context of the research clear (country, setting)? \\
\hline \multirow[t]{2}{*}{ Method } & 5. Do the authors state the research methods used? \\
\hline & 6. Do the authors give an argument for the methods chosen? \\
\hline \multirow[t]{3}{*}{ Data analysis and findings } & 7. Are the data analyzed in an adequate and precise way? \\
\hline & 8. Are the results clearly presented? \\
\hline & 9. Is it clear how the data were used to formulate the findings? \\
\hline \multirow[t]{2}{*}{ Conclusion } & 10. Have the authors addressed the research question? \\
\hline & 11. Are the limitations of the study detailed by the authors? \\
\hline
\end{tabular}

Fig. 1 Flow chart of identified and included studies
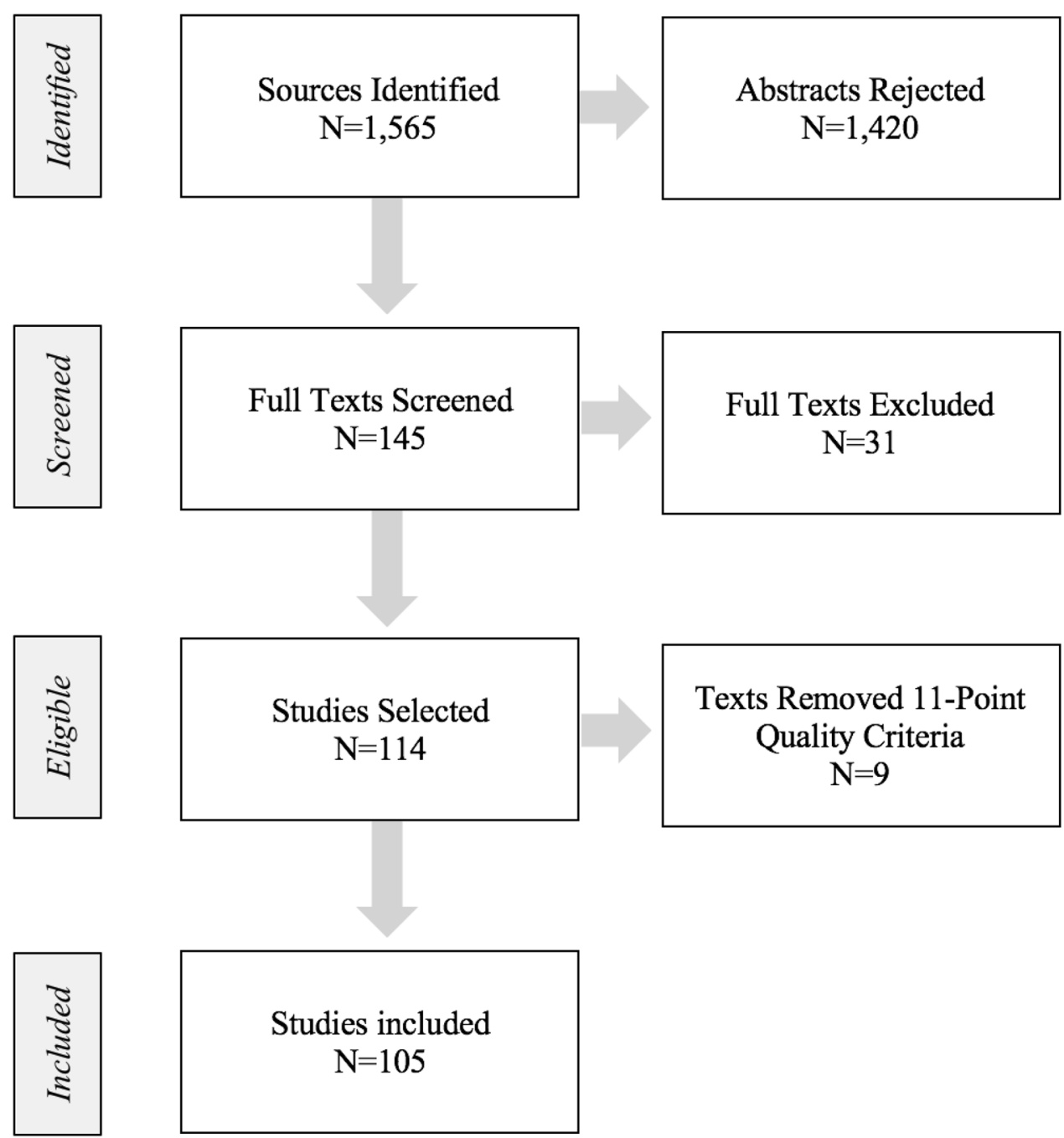

research topic, type of article (e.g., quantitative, qualitative), method used (e.g., questionnaire, interviews) and the focus and method of analysis. As the review was interested in learning within and across organizations, articles were then coded for the level of learning (e.g., individual, team), in line with Rashman et al. (2009). Similarly, following Senge and Sterman's (1992) seminal work on systems thinking and organizational learning, articles were also coded for the 
learning type (e.g., feedback, reflection). Barriers and enablers of learning were coded to understand the conditions in which learning is most effective across different disciplines and contexts. To capture the relevance of the learning insights for sustainability, the research context, motivation for learning, and outcome of the study with regard to sustainability were also coded.

The first author proceeded to code a sample of 20 articles for the above themes. Through this process it became clear that an additional aspect was not captured in the analysis. Despite capturing the research context and motivation for learning with regard to sustainability, the sampling process revealed that motivation for learning had a stronger relationship with learning outcomes than was anticipated. Specifically, it became clear that motivation for engaging in sustainability projects could influence the type and level of learning adopted. We considered this in the second round of coding by capturing whether the paper was framing sustainability as an opportunity or something to be mitigated and adapted to. Once all authors had confirmed the new coding frame, the first author proceeded to analyze the full texts of all 105 articles. This resulted in five main themes which we detail in the following section. Table 2 offers a summary of the five themes, key findings, and exemplar articles.

\section{Findings}

\section{Basic Characteristics of Learning for Sustainability Research}

Figure 2 shows that research on learning for sustainability has been growing in recent years. Sixty percent of all articles in our sample were published between 2016 and 2020. The rapid growth in publications during this time could align with the launch of the SDGs Global Framework on January 1,2016 , that has since been widely adopted by universities, governments, and industry players across the world. Figure 2 also demonstrates that the majority of articles published on learning for sustainability come from disciplines outside of business and management. Table 3 offers a more detailed break-down of the distribution of articles published in business and management, and sustainability sciences journals, showing that the most frequently published journals were Sustainability, with ten publications, and Environmental Science and Policy and Journal of Cleaner Production, both with eight publications. The higher rate of publications in Sustainability and Journal of Cleaner Production could be attributed to the fact that both are multidisciplinary journals that accept submissions from a broad spectrum of disciplines, including business and management. While the other journals are more disciplinary specific.
Table 3 also illustrates that most of the literature consists of qualitative studies, making up sixty-five percent of all articles. This focus on qualitative data is not surprising given that learning and sustainability are considered ambiguous concepts that can be defined and interpreted in multiple different ways (Barkemeyer et al., 2014; Ellström, 2010; Hopwood et al., 2005). It is therefore understandable that research on learning for sustainability is still in the exploratory and meaning-making phase that lends itself more to qualitative research methods (Elliot \& Timulak, 2005; Mayring, 2014).

\section{Instrumental vs. Reflexive Learning}

The literature showed that there were variations in the terminology used to conceptualize learning across all research disciplines; however, the meanings were similar (van de Kerkhof and Wieczorek, 2004; Pallett \& Chilvers, 2013; Pahl-Wostl, 2009). The first form of learning identified in the literature was when the objective was to fix a problem within existing structures and did not attempt to alter or challenge that existing structure (Restrepo et al., 2018). Several articles related this process to 'single-loop' learning (PahlWostl, 2009; Restrepo et al., 2018; Wicki \& Hansen, 2019), referring to Argyris and Schön's seminal works on organizational learning (Argyris, 1976; Argyris \& Schon, 1974; 1978), while other articles referred to this process as 'instrumental' learning (Lankester, 2013; Moyer et al., 2014). The second form of learning was when fundamental world views and values were challenged and modified, not just behaviors, usually as a result of a particular experience and a process of reflection (Heikkila \& Gerlak, 2019; Sol et al., 2018). This type of learning was described as both 'double-loop' learning (Heikkila \& Gerlak, 2019; Willems et al., 2018), again referring to Argyris and Schön, and 'transformative' learning (Lankester, 2013; Pallett \& Chilvers, 2013). The third form of learning was 'triple-loop' learning, a concept inspired by Argyris and Schön's earlier work on learning loops (Tosey et al., 2012), and is described as when processes are changed specifically to foster double-loop learning or learning how to learn within organizations (Heikkila \& Gerlak, 2019; Totin et al., 2018). Boyd and Osbahr (2010) also referred to 'multi-loop' or 'reflexive' learning which was described by the authors as a combination of all previous forms of learning. One final observation on learning concepts that arose from the literature was the notion of 'unlearning.' There were two distinct ways that 'unlearning' was described in the literature. Firstly, as a positive process whereby "firms eliminate old logic and make room for new ones" (Sinkula, 2002 as cited in Hasanudin et al., 2019, p. 1358; Oelze et al., 2016; Lozano, 2014). Secondly, as a negative phenomenon that occurs when "organizations seem to forget lessons learned" (Sánchez \& Mitchell, 2017, p. 200). 


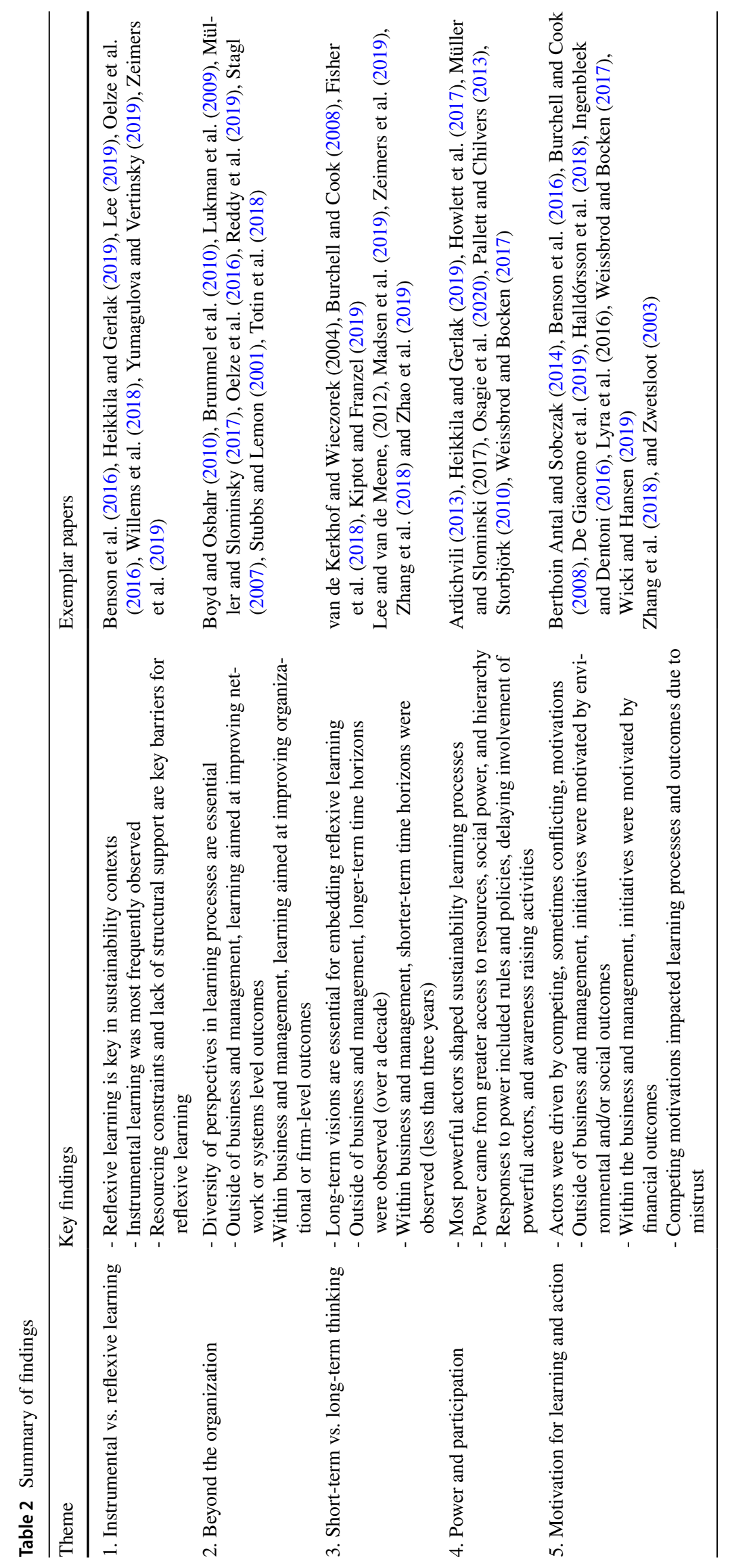


Fig. 2 Number of learning for sustainability publications over time
NUMBER OF LEARNING FOR SUSTAINABILITY PUBLICATIONS OVER TIME

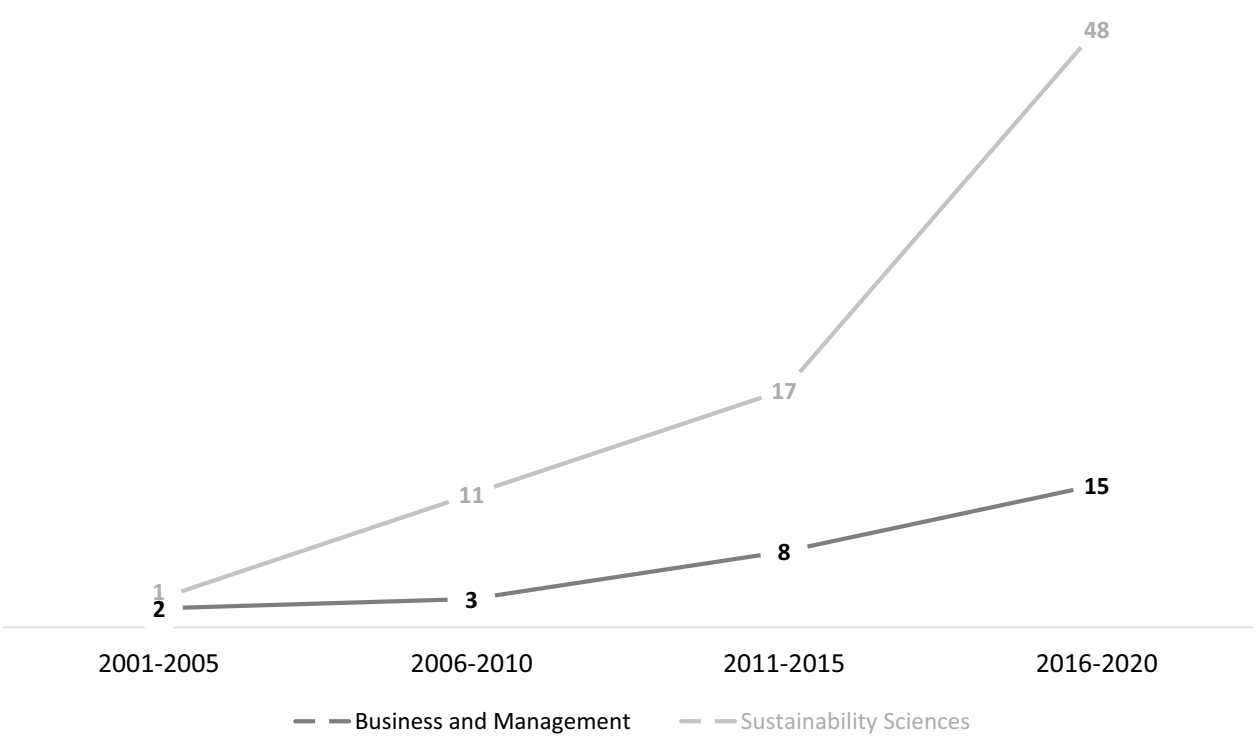

There was a shared understanding across all research disciplines that multi-loop or reflexive learning is required in the context of sustainability (Boyd \& Osbahr, 2010; PahlWostl, 2009; Pallett \& Chilvers, 2013; Sol et al., 2018; Totin et al., 2018). However, studies from the environmental sciences and urban planning found that instrumental learning was much more frequently observed as organizations preferred to stay within their current structures and practices (Benson et al., 2016; Willems et al., 2018). For example, Willems et al. (2018) looked at the Dutch Transport and Infrastructure Authority during a time of structural organizational renewal, and found that despite attempts to shift organizational culture and practices (double and triple-loop learning) to meet the growing complexity of the environment, researchers instead observed a refinement of existing organizational practices (single-loop or instrumental learning).

Common reasons for staying within current structures were institutional structures themselves not supporting more systematic or disruptive change (Halldórsson et al., 2018; Heikkila \& Gerlak, 2019), and resourcing constraints (Burchell \& Cook, 2008). A lack of institutional structural support was observed either through organizational cultures that did not support multi-loop or reflexive learning processes such as learning from failure (Heikkila \& Gerlak, 2019; Wicki \& Hansen, 2019), and organization-wide adoption of acquired knowledge and skills (Yumagulova \& Vertinsky, 2019; Zeimers et al., 2019). Similarly, many studies identified a lack of time and social capital as barriers to achieving double or triple-loop learning for sustainability
(Lee, 2019; Oelze et al., 2016; Sánchez \& Mitchell, 2017). This was particularly apparent at the network level, where learning processes relied on contributions from multiple organizations and representatives (Boyd \& Osbahr, 2010; Halldórsson et al., 2018).

\section{Beyond the Organization}

Two ways of understanding the level at which learning took place came from the literature; 1 ) where the learning process took place, and 2) where learning outcomes aimed to add value. As an example, Boyd and Osbahr (2010) conducted a comparative study of four government organizations in the UK and sought to understand how each captured informal and formal learning across their networks to better respond to climate change. The study found that although each organization relied on the same networks and information (processes), their ability to capture the value from learning outcomes varied substantially across the four organizations dependent on factors relating to organizational culture and resourcing (Boyd \& Osbahr, 2010).

Across all research disciplines, it was apparent that diverse perspectives were desirable in sustainability learning processes (Berthoin Antal \& Sobczak, 2014; Stagl, 2007; Stubbs \& Lemon, 2001; Totin et al., 2018). Despite the occasional focus on individual learning (Lankester, 2013; Moyer et al., 2014; Rietig \& Perkins, 2018), it was much more prominent for studies across all disciplines to look at learning from team (Kiptot \& Franzel, 2019; Lozano, 2014), organizational (Benn et al., 2013; Zhang et al., 2018) 
Table 3 Academic journals and method underlying articles

\begin{tabular}{|c|c|c|c|c|c|}
\hline Academic Journal & Articles & Theoretical & Quant & Mixed & Qual \\
\hline 1. Academy of Management Learning \& Education & 1 & & & & 1 \\
\hline 2. AMBIO & 1 & & & & 1 \\
\hline 3. Advances in Developing Human Resources & 2 & 1 & & & 1 \\
\hline 4. Building Research \& Information & 1 & & & & 1 \\
\hline 5. Business \& Society & 1 & & & & 1 \\
\hline 6. Business Ethics, The Environment \& Responsibility & 1 & & & & 1 \\
\hline 7. Business Strategy \& the Environment & 3 & & 1 & & 2 \\
\hline 8. Canadian Journal of Development Studies & 1 & & & & 1 \\
\hline 9. Climate \& Development & 1 & & & & 1 \\
\hline 10. Climatic Change & 3 & & & & 3 \\
\hline 11. Entrepreneurship and Sustainability Issues & 1 & & 1 & & \\
\hline 12. Environment \& Planning A & 1 & & & & 1 \\
\hline 13. Environment \& Planning D: Politics and Space & 1 & & & & 1 \\
\hline 14. Environmental Education Research & 2 & & & 1 & 1 \\
\hline 15. Environment, Development and Sustainability & 1 & & & & 1 \\
\hline 16. Environmental Impact Assessment Review & 1 & 1 & & & \\
\hline 17. Environmental Innovation \& Societal Transitions & 2 & & & & 2 \\
\hline 18. Environmental Management & 2 & & & & 2 \\
\hline 19. Environmental Science \& Policy & 8 & & 1 & 2 & 5 \\
\hline 20. European Sport Management Quarterly & 1 & & & & 1 \\
\hline 21. Futures & 2 & 1 & & & 1 \\
\hline 22. Global Environmental Change & 3 & 1 & & 1 & 1 \\
\hline 23. Global Environmental Politics & 1 & & & & 1 \\
\hline 24. Human Resource Development Review & 1 & 1 & & & \\
\hline 25. Innovation: The European Journal of Social Science Research & 1 & & & & 1 \\
\hline 26. International Journal of Agricultural Sustainability & 1 & & & & 1 \\
\hline 27. International Journal of Climate Change Strategies and Management & 1 & & & & 1 \\
\hline 28. International Journal of Lifelong Education & 1 & & & & 1 \\
\hline 29. International Journal of Management Economics & 1 & & 1 & & \\
\hline 30. International Journal of Sustainable Development and World Ecology & 2 & 1 & 1 & & \\
\hline 31. Journal of Agricultural Science and Technology & 1 & & & 1 & \\
\hline 32. Journal of Business and Industrial Marketing & 1 & & & & 1 \\
\hline 33. Journal of Business Ethics & 2 & 1 & & & 1 \\
\hline 34. Journal of Cleaner Production & 8 & 2 & & & 6 \\
\hline 35. Journal of Environmental Management & 2 & & & 1 & 1 \\
\hline 36. Journal of Environmental Planning and Management & 4 & 1 & & & 3 \\
\hline 37. Journal of Environmental Policy \& Planning & 2 & & 1 & & 1 \\
\hline 38. Journal of European Public Policy & 1 & & & & 1 \\
\hline 39. Journal of Management Development & 1 & & & & 1 \\
\hline 40. Journal of Organizational Change Management & 1 & 1 & & & \\
\hline 41. Journal of Public Administration Research and Theory & 1 & & 1 & & \\
\hline 42. Journal of Purchasing \& Supply Management & 1 & & 1 & & \\
\hline 43. Journal of Workplace Learning & 1 & & & & 1 \\
\hline 44. Management Learning & 1 & & & & 1 \\
\hline 45. Management \& Organization Review & 1 & & 1 & & \\
\hline 46. Management Research Review & 1 & & 1 & & \\
\hline 47. Organization \& Environment & 3 & & 1 & 1 & 1 \\
\hline 48. Policy \& Society & 1 & & & & 1 \\
\hline 49. Policy Sciences & 1 & & & & 1 \\
\hline 50. Public Health Reports & 1 & & & & 1 \\
\hline
\end{tabular}


Table 3 (continued)

\begin{tabular}{|c|c|c|c|c|c|}
\hline Academic Journal & Articles & Theoretical & Quant & Mixed & Qual \\
\hline 51. Risk, Hazards \& Crisis in Public Policy & 1 & & & & 1 \\
\hline 52. Safety Science & 1 & & & & 1 \\
\hline 53. Sport in Society & 1 & 1 & & & \\
\hline 54. Sustainability & 10 & 1 & 3 & 1 & 5 \\
\hline 55. Sustainability Science & 3 & & & & 3 \\
\hline 56. Sustainable Development & 1 & 1 & & & \\
\hline 57. Technological Forecasting \& Social Change & 1 & 1 & & & \\
\hline 58. Waste Management and Research & 1 & & & & 1 \\
\hline \multirow[t]{2}{*}{ 59. Water (Switzerland) } & 2 & & & & 2 \\
\hline & 105 & 15 & 14 & 8 & 68 \\
\hline
\end{tabular}

and inter-organizational network (Axelsson et al., 2013; Bachofen et al., 2015; Fisher et al., 2018; Lee, 2019) levels. Research outside of business and management predominantly examined learning processes with the aim of improving network-level outcomes and responses to sustainability (e.g., Brummel et al., 2010; Lukman et al., 2009; Müller \& Slominsky, 2017). However, the business and management literature, with only a few exceptions (e.g., Benn et al., 2013; Ryan et al., 2012; Scully-Russ, 2015), predominantly examined learning with the aim of improving organizational- or firm-level outcomes and performance (e.g., Berthoin Antal \& Sobczak, 2014; Oelze et al., 2016; Reddy et al., 2019; Zwetsloot, 2003).

The above findings suggest that research outside of business and management is understanding sustainability from a systems level perspective, evidenced by the aim of improving multiple actors' capacity to respond to sustainability. However, business and management scholars continue to view learning for sustainability through their own disciplinary silo; where acquiring new skills and knowledge is considered valuable but largely for its ability to improve firm performance.

\section{Short-Term vs. Long-Term Thinking}

Given the complexity of sustainability, it is important to have a long-term vision for sustainability projects as it allows for embedding reflexive and multi-loop learning processes (Zhang et al., 2018). Many studies from research outside of business and management focused on projects with longer-term time horizons, often over a decade (Fisher et al., 2018; Kiptot \& Franzel, 2019; Lee \& Meene, 2012). Van de Kerkhof and Wieczorek (2004) argue that anything less than a 30-year vision for sustainability projects limits the creativity of solutions, as people remain confined by current political and social landscapes. In the business and management literature, however, sustainability projects generally had a much smaller timeframe, often less than three years
(Berthoin Antal \& Sobczak, 2014; Burchell \& Cook, 2008; Zeimers et al., 2019). Further, projects were often presented through the lens of cost-benefit (Madsen et al., 2019; Zhao et al., 2019) that are inherently dictated by annual performance reviews and measures. This short-term thinking by the business sector can be seen as a major challenge for embedding reflexive and multi-loop learning processes, and transitioning from small-scale, incremental sustainability responses to more radical and innovative solutions.

\section{Power and Participation}

The literature showed that power relations have great influence in shaping organizational culture around sustainability (Ardichvili, 2013), and that it was often the most powerful actors in the learning process that shaped the outcomes of sustainability projects (Howlett et al., 2017; Weissbrod \& Bocken, 2017; Storbjörk, 2010; Müller and Slominski, 2017). The three main sources of power consisted of greater access to resources, social power, and hierarchy. In development and planning studies, the biggest and wealthiest cities had greater decision-making influence and received the most funding and support (Lee, 2019; Lee and van de Meene, 2012). In conservation and natural resource management studies, social power was demonstrated by the exclusion of marginalized indigenous actors in decision-making processes (Heikkila \& Gerlak, 2019; Yumagulova \& Vertinsky, 2019). Social power was also demonstrated in transdisciplinary research projects within the social sciences where it was found that researchers, due to their higher social and educational status, would often intimidate other actors and impact the group's ability to establish shared mental models and visions (Ely et al., 2020; Roux et al., 2017). In business and management studies, top leadership determined a project team's course of action and overall performance measures (Osagie et al., 2020; Pallett \& Chilvers, 2013; Weissbrod \& Bocken, 2017). 
Responses to these power imbalances ranged from embedding rules and policies around participation and decisionmaking processes (Heikkila \& Gerlak, 2019) to strategically timing when top leadership were brought in to review a project (Weissbrod \& Bocken, 2017). Ardichvili (2013) drew specific attention to the role of HRD for managing power dynamics within organizational sustainability initiatives by HRD managers leading activities "focused on raising awareness of issues of power and power interrelationships between organizational players" (p. 470).

\section{Motivation for Learning and Action}

The analysis suggests that actors from different sectors are driven by competing, sometimes conflicting, motivations when engaging in learning for sustainability. Initiatives examined in the literature outside of business and management were mostly motivated to engage in sustainability learning by achieving environmental or sustainability outcomes, i.e., preparing for climate change and other extreme events (Benson et al., 2016; Boyd \& Osbahr, 2010; Zhang et al., 2018). However, initiatives from within the business and management literature were mostly motivated to engage in sustainability learning by minimizing risks and maximizing profits (Weissbrod \& Bocken, 2017; Zhao et al., 2019; Zwetsloot, 2003). New or threatened government regulation (De Giacomo et al., 2019; Zwetsloot, 2003), increased pressure from stakeholders (Berthoin Antal \& Sobczak, 2014; Ingenbleek \& Dentoni, 2016), or market predictions (Wicki \& Hansen, 2019; Wossen et al., 2013) were observed as the biggest 'triggers' for businesses engaging in learning for sustainability.

The literature revealed that a common outcome of competing motivations among participants in multi-stakeholder learning processes was mistrust (Lyra et al. 2016; Burchell \& Cook, 2008). Tension and mistrust were observed as a result of actors having competing motivations or aims for participating in sustainability initiatives, i.e., business stakeholders predominantly prioritizing financial outcomes and not-for-profits and government predominantly prioritizing environmental or social outcomes (Burchell \& Cook, 2008; Lyra et al., 2017). Trust, and its role in facilitating dialogue, was found to have great influence over the effectiveness of learning processes, and even the success of entire sustainability initiatives (Halldórsson et al., 2018; Müller \& Slominsky, 2017; Rietig \& Perkins, 2018). Thus, illustrating the important role that motivation and trust can play in collaborative and multi-stakeholder sustainability initiatives.

\section{Discussion and Research Agenda}

In this section, we look specifically at learning for sustainability from a business and management perspective. We consider key insights obtained from other fields as a starting point for describing pressing challenges companies face when learning for sustainability. Broader implications of this work for future business and management research and practice are summarized into two key propositions. Table 4 summarizes our research agenda for future business and management research on learning for sustainability.

\section{Reflexivity in Practice and Research}

Our findings suggest that achieving meaningful sustainability solutions requires time to embed sustainability values throughout teams, projects, organizations and networks. Specifically, sustainability requires time for reflective and reflexive learning. There are various definitions of reflective and reflexive learning, and while there are some similarities between the two concepts there are also clear distinctions (Cotter \& Cullen, 2012). Reflection as a practice is the process whereby an individual reflects back on an experience or event (Roulston et al., 2008) and reflective learning is the act of objectively reflecting on our own actions or concepts of self (Cotter \& Cullen, 2012; Cunliffe, 2004). The importance of reflection in learning for sustainability was raised consistently in the literature. While this process of (self-) reflection is indeed an essential component for progressing toward sustainability, Cunliffe (2004) argues that we must take reflection a step further, to reflexive learning, and consider the broader social constructs that shape the realities in which we exist and act, in order to change them. Reflective learning is therefore considered a necessary step toward 'reflexive learning,' and 'reflexive learning' a necessary step toward more radical and meaningful responses to sustainability. However, recent literature suggests that there is no guarantee that even reflexive learning will lead to positive outcomes for sustainability. Sharp and Threadgold (2020) introduced the notion of 'reflexive complicity' in their study on gender marginalization, stating that:

reflexive complicity is performed when one knows about unequal social relations or forms of marginalization, can observe them and claim to want things to change, but there are no significant changes in practice by the individual and little effort to engage in situational interventions that make a difference (pp. 619-620).

The term 'reflexive complicity' could explain the dilemma we observe in business, where the issue of sustainability is 
Table 4 Summary research agenda

\begin{tabular}{|c|c|c|}
\hline Theoretical focus & Phenomena & Research question \\
\hline Critical reflexive learning & $\begin{array}{l}\text { Relationships between reflexive complicity, critical } \\
\text { reflexive learning and sustainability outcomes. (1) } \\
\text { Complicity and motivation for reflexive learning } \\
(1,5) \\
\text { Time and reflexive learning }(1,3) \\
\text { Reflexive complicity }(1,5)\end{array}$ & $\begin{array}{l}\text { How does reflexive complicity and criti- } \\
\text { cal reflexive learning shape sustainability } \\
\text { outcomes? } \\
\text { How can organizations and multi-stakeholder } \\
\text { initiatives promote critical reflexive learning? } \\
\text { How does motivation shape complicit versus } \\
\text { critical engagement with reflexive learning } \\
\text { for sustainability outcomes? } \\
\text { How do learning processes evolve in long-term } \\
\text { sustainability initiatives? } \\
\text { How does time in longer-term sustainability } \\
\text { initiatives influence critical reflexive learning } \\
\text { and sustainability outcomes? } \\
\text { What incentivizes businesses to take a longer- } \\
\text { rather than a shorter-term time horizon when } \\
\text { developing their sustainability initiatives? } \\
\text { When and how is reflexive complicity being } \\
\text { observed in business and management sus- } \\
\text { tainability activities? }\end{array}$ \\
\hline Power and value & $\begin{array}{l}\text { Complexity of power relations in collaboration } \\
\text { processes }(2,4) \\
\text { Education and training activities for raising aware- } \\
\text { ness of power dynamics in sustainability initiatives } \\
\text { (4) } \\
\text { Relationships between entrenched power structures, } \\
\text { decision-making, and learning processes }(4) \\
\text { The passive participants in learning and decision- } \\
\text { making processes }(2,4) \\
\text { Relationships between value, single/double/triple- } \\
\text { loop and reflexive learning, and responses to } \\
\text { sustainability }(1,4)\end{array}$ & $\begin{array}{l}\text { How does power influence learning processes } \\
\text { and outcomes in multi-stakeholder and/or } \\
\text { transdisciplinary sustainability projects? } \\
\text { What education and training activities are most } \\
\text { effective for raising employee awareness of } \\
\text { power imbalances in corporate sustainability } \\
\text { initiatives? } \\
\text { How do decision-making practices shape } \\
\text { learning processes in sustainability projects? } \\
\text { What are the determinants of active versus pas- } \\
\text { sive engagement in sustainability initiatives? } \\
\text { What will enable businesses to engage diverse } \\
\text { voices from within and across organizational } \\
\text { boundaries in their sustainability initiatives } \\
\text { and decision-making? } \\
\text { How do diverse perspectives on value, and } \\
\text { different types of learning, shape responses } \\
\text { to sustainability? }\end{array}$ \\
\hline
\end{tabular}

After each phenomenon proposed for future research, numbers are listed in parentheses that relate to the themes from the literature review findings, as presented in Table 2

acknowledged, and there are claims of wanting to change to address it, but we continue to see a lack of meaningful actions to address the issues. This dilemma suggests that it is not just reflexivity itself that is important for achieving meaningful sustainability outcomes, but our motivations for engaging in reflexivity are equally important. If the motivation for businesses engaging in sustainability is to identify threats, appease stakeholders and maintain the status quo rather than find meaningful sustainability solutions, then reflexivity will likely result in business-as-usual responses. On the contrary, reflexivity that is motivated by achieving meaningful sustainability solutions could arguably lead to more radical responses. In Cunliffe's more recent work (2016), she refers to critical reflexive learning and describes the process as "examining our own assumptions, decisions, actions, interactions, and the assumptions underpinning organizational policies and practices and the intended and potentially unintended impact" of them (p. 741). This combination of self- and critical- reflexivity aligns with our understanding of what is required for more meaningful responses to sustainability; thereby challenging the existing structures, policies and practices that support unsustainable behaviors and actions from individuals and organizations. Critical reflexivity around company sustainability values and motivations, and the systems that these exist within, may help in overcoming reflexive complicity in company sustainability responses. The concept of 'reflexive complicity' itself could also benefit from further empirical investigation within the context of business sustainability to determine when and how the phenomenon is observed in practice. 
Future business and management research could benefit by exploring the complex relationships between company motivations, reflexive complicity, critical reflexive learning and sustainability outcomes. As company motivations were also found in the literature to be a point of tension between actors in multi-stakeholder initiatives for sustainability, outcomes from further research on critical reflexive learning and motivations could be used to better prepare stakeholders for more trusting and fruitful collaborations in practice.

Findings from our review show that business and management research often focused on proving or exploring relationships between learning activities and performance or product innovation outcomes, rather than sustainability outcomes. In practice, it was found that businesses were slowed in their progress toward sustainability due to a businessas-usual lens on value; however, the tendency for business and management scholars to motivate their research through outcomes of firm performance could be argued as the same dilemma. Motivating business and management research on learning for sustainability by the potential benefits to firm performance i.e., competitive advantage and product innovation, only reinforces the same business-as-usual value structures that prioritize the firm over all else. This framing of the firm over all else perpetuates the idea that sustainability is a secondary consideration for businesses, after profits, and allows for slow and incremental responses to sustainability challenges. Cullen (2020) drew similar conclusions in his review of the responsible management literature stating that there was a "need for business schools to resolve the tension between capitalism and social/environmental responsibility" (p. 768). Our findings align with those of Cullen (2020), in suggesting that researchers, especially those operating in a business school context, may have the same tendencies toward reflexive complicity as practitioners.

We therefore join the growing body of researchers who are calling for more reflexive scholarship when it comes to sustainability (Ardichvili, 2013; Laasch et al., 2020; Schaefer et al., 2015; Shrivastava, P., Ivanaj, S. \& Persson, $S, 2013)$. We encourage researchers to engage in critical reflexivity and challenge the underlying assumptions and approaches that have traditionally been applied to research on learning for sustainability, which has largely adopted a causal approach to understanding relationships between sustainability, learning, and firm performance. We argue that deeper and more critical reflection is needed on the actions required for meaningful sustainability outcomes and the societal or systemic structures that enable or limit these actions. For example, one fundamental concern that arose from the literature is the need for businesses to adopt longer-term time horizons when developing their sustainability initiatives. Longitudinal studies with companies or multi-stakeholder initiatives that have adopted long-term strategies for sustainability could therefore be conducted to understand the evolution of learning processes that facilitate these strategies over time. Engaging in critical reflexive learning, as researchers, and allowing sustainability outcomes to motivate our research rather than firm performance could be a key component for a more radical transition toward sustainability.

\section{Broadening Our Understanding of Power and Value}

Our review revealed that organizations are increasingly engaging in inter-organizational and network-level collaborations with diverse actors to tackle sustainability challenges. This increase in the diversity of actors collaborating on sustainability projects impacts the complexity of learning processes. The literature showed that for sustainability collaborations to be successful, all actors must feel comfortable and supported to speak up and participate in the group learning process as it is vital for establishing shared mental models, problem definitions, and shared goals/visions. However, our review found that power imbalances directly impacted the level at which certain actors felt comfortable to participate and voice their opinions in collaborative learning processes.

The literature on power could help to explain why businesses that broaden the range of actors in their sustainability activities also experience greater complexity in learning processes (Brennan \& Tennant, 2018). As an example, embedding sustainable practices across a company's supply chain often results in open dialogue and inquiry with community representatives in countries where the company's raw materials are sourced. Findings from the research outside of business and management revealed that engagements of this kind commonly saw participants who were from a vulnerable or marginalized population (Heikkila \& Gerlak, 2019), did not speak the same 'language' as those leading the learning process (Lee and van de Meene, 2012) or were less educated (Roux et al., 2017). All of which were found to influence the power dynamics within group learning processes and reduce the level of participation and engagement required for meaningful sustainability action. To better understand the role of power in learning processes for sustainability, future business and management research could benefit by focusing on the increasingly complex ways that power influences learning processes and outcomes in collaborative sustainability projects. Building on research from Ardichvili (2013), future research could also explore the ways in which learning, through education and training activities, can be used to minimize the effects of power in sustainability initiatives. Understanding power in learning processes, and the role of learning processes for raising awareness of power relations, will be particularly important as we observe more networked and multi-stakeholder initiatives for sustainability. Similarly, we reiterate the need for more engaged, 
networked and international research collaborations on learning for sustainability. The complexity and far-reaching impacts of sustainability challenges requires a broadening of our thinking that goes beyond firm-level responses and disciplinary silos.

Our review also identified power as a factor influencing decision-making processes in sustainability projects. It showed that decision-makers on sustainability projects were largely members of senior and executive management, and the sustainability responses they pursued were mostly instrumental. The literature on power and decision-making could help to explain this relationship as a 'mobilization of bias,' defined as "a set of predominant values, beliefs, rituals, and institutional procedures that operate systematically and consistently to the benefit of certain persons and groups at the expense of others" (Bachrach and Baratz, 1970 as cited in McCright \& Dunlap, 2010, p. 106). Mobilization of bias means that the powerful actors, in this case senior management, are able to set the agenda for the sustainability issues that align with their interests and prevent actions on sustainability issues that challenge their interests (McCright $\&$ Dunlap, 2010).

Our review suggests that alternative ways of measuring the success of management, sustainability projects and companies could free up managers to invest in critical reflexive learning processes that align with longer-term and more radical responses to sustainability. Future business and management research could therefore explore how we have traditionally understood value in companies and how this relates to critical reflexive learning. In addition, supportive research could explore the types of learning observed in companies that successfully foster more radical responses to sustainability and the value structures that helped to support these processes. This calls for exploring how organizations can change entrenched power structures in decision-making. To conclude, establishing a broader understanding of how businesses can value and engage diverse voices in their sustainability initiatives and decision- making could offer a fruitful avenue for future research on sustainability.

\section{Limitations}

Several limitations to this research need to be noted. First, data used for this review were limited to English language journal publications and did not include books, book chapters or conference proceedings. Given the global nature of sustainability, and the fact that current research is dominated by European and North American perspectives, future studies should also engage with researchers and study participants from diverse cultural backgrounds who are embedded in areas most affected by sustainability issues. We propose this could be done in two ways; 1) expanding future review studies to include articles published in languages other than
English, and 2) conducting empirical studies on learning for sustainability that aim to capture insights from underrepresented populations. Second, there is a potential bias in the key-search terms used for data collection. To narrow the search down, a decision was made to use terms related to the level where learning took place, i.e., 'team,' 'organization,' and 'network' learning. After reviewing the literature, it became clear that there were other forms of learning descriptors that could have broadened the articles reviewed, for example types of learning i.e., 'social' learning, 'participatory' learning, 'transformational' learning. Despite our review still capturing literature on these learning types, extensions of this review could re-examine the key-search terms used to ensure the breadth of learning types are captured from across all research disciplines. Finally, in the space of just five years (2016-2020) there was a $60 \%$ increase in publications on learning for sustainability across disciplines. While this is not a limitation to our study, this trend in publication growth signifies the rapidly evolving nature of learning for sustainability as a field of study. To capture future insights and understandings of learning for sustainability, it could be advantageous to conduct similar cross-disciplinary literature reviews on learning for sustainability on a regular basis.

\section{Concluding Remarks}

Current research has focused on disciplinary-specific approaches to learning for sustainability. Our review aligns with calls from prior research for cross-disciplinary and multi-stakeholder approaches to sustainability. It offers a deepened understanding of the challenges organizations and multi-stakeholder initiatives face when learning for sustainability, including entrenched power relations, and traditional decision-making and value structures. We introduce 'reflexive complicity' as a conceptual lens for understanding the slow progress we see in societal responses to sustainability challenges. We argue that in order to overcome these challenges and realize meaningful sustainability outcomes, more critical reflexive learning is needed on what motivates engagement with sustainability from academia and practice. Shifting how we motivate business and management research on learning for sustainability, in a way that prioritizes sustainability outcomes over firm performance, could allow for more engaged and transdisciplinary research collaborations and bring us a step closer to understanding how to embed critical reflexive learning processes into businesses. Similarly, breaking patterns of reflexive complicity from key actors in businesses could also see a shift toward more radical and long-term responses to sustainability in practice. 
Acknowledgements We thank the European Group for Organization Studies (EGOS) 'Organizing for Climate Change' subtheme community for their invaluable feedback on our paper. In particular, we thank Christopher Wright, Daniel Nyberg, and Vanessa Bowden for their suggestion of exploring 'reflexive complicity' as a conceptual contribution of our review.

Open Access This article is licensed under a Creative Commons Attribution 4.0 International License, which permits use, sharing, adaptation, distribution and reproduction in any medium or format, as long as you give appropriate credit to the original author(s) and the source, provide a link to the Creative Commons licence, and indicate if changes were made. The images or other third party material in this article are included in the article's Creative Commons licence, unless indicated otherwise in a credit line to the material. If material is not included in the article's Creative Commons licence and your intended use is not permitted by statutory regulation or exceeds the permitted use, you will need to obtain permission directly from the copyright holder. To view a copy of this licence, visit http://creativecommons.org/licenses/by/4.0/.

\section{References}

\section{*All references marked with an asterisk are included in the systematic review}

Ardichvili, A. (2013). The role of HRD in CSR, sustainability, and ethics: a relational model. Human Resource Development Review, 12(4), 456-473.

Argyris, C., \& Schon, D. A. (1974). Theory in practice. Jossey-Bass.

Argyris, C., \& Schon, D. A. (1978). Organizational learning: A theory of action perspective. Addison-Wesley.

Argyris, C., \& Schon, D. A. (1996). Organizational learning II: Theory, method, and practice. Reading, MA: Addison- Wesley.

Argyris, C. (1976). Single-loop and double-loop models in research on decision making. Administrative Science Quarterly, 21, 363-375.

*Axelsson, R., Angelstam, P., Myhrman, L., Sädbom, S., Ivarsson, M., Elbakidze, M., \& Törnblom, J. (2013). Evaluation of multi-level social learning for sustainable landscapes: Perspective of a development initiative in Bergslagen. Sweden. Ambio, 42(2), 241-253.

*Bachofen, C., Sundstrom, R., Iqbal, F. Y., \& Suarez, P. (2015). Participation, learning and innovation in adaptation to climate change: Development \& Climate Days 2013. Climate and Development, 7(2), 192-195.

Bansal, P. (2003). From issues to actions: The importance of individual concerns and organizational values in responding to natural environmental issues. Organization Science, 14(5), 510-527.

Barkemeyer, R., Holt, D., Preuss, L., \& Tsang, S. (2014). What happened to the "development" in sustainable development? Business guidelines two decades after Brundtland. Sustainable Development, 22(1), 15-32.

Barth, M., \& Michelsen, G. (2013). Learning for change: An educational contribution to sustainability science. Sustainability Science, 8(1), 103-119.

Battilana, J., \& Dorado, S. (2010). Building sustainable hybrid organizations-the case of commercial microfinance organizations. Academy of Management Journal, 53(6), 1419-1440.

Bechky, B. A. (2003). Sharing meaning across occupational communities: The transformation of understanding on a production floor. Organization Science, 45(3), 312-330.
Bell, B. S., Kozlowski, S. W. J., \& Blawath, S. (2012). Team learning: A theoretical integration and review. The Oxford Handbook of Organizational Psychology, 2, 859-909.

Benn, S., Edwards, M., \& Angus-Leppan, T. (2013). Organizational learning and the sustainability community of practice: The role of boundary objects. Organization and Environment, 26(2), 184-202.

*Benson, D., Lorenzoni, I., \& Cook, H. (2016). Evaluating social learning in England flood risk management: An "individual-community interaction" perspective. Environmental Science and Policy, 55, 326-334.

*Berthoin Antal, A., \& Sobczak, A. (2014). Culturally embedded organizational learning for global responsibility. Business and Society, 53(5), 652-683.

*Boyd, E., \& Osbahr, H. (2010). Responses to climate change: Exploring organisational learning across internationally networked organisations for development. Environmental Education Research, 16(5-6), 629-643.

Brennan, G., \& Tennant, M. (2018). Sustainable value and trade-offs: Exploring situational logics and power relations in a UK brewery's malt supply network business model. Business Strategy and the Environment, 27(5), 621-630.

Brønn, P., \& S. and Vidaver-Cohen, D. (2009). Corporate motives for social initiative: Legitimacy, sustainability, or the bottom line? Journal of Business Ethics, 87, 91-109.

*Brummel, R. F., Nelson, K. C., Souter, S. G., Jakes, P. J., \& Williams, D. R. (2010). Social learning in a policy-mandated collaboration: Community wildfire protection planning in the eastern United States. Journal of Environmental Planning and Management, 53(6), 681-699.

*Burchell, J., \& Cook, J. (2008). Stakeholder dialogue and organisational learning. Business Ethics: A European Review, 17(1), $35-46$.

Camps, J., \& Majocchi, A. (2010). Learning atmosphere and ethical behavior, does it make sense? Journal of Business Ethics, 94(1), 129-147.

Cotter, R. J., \& Cullen, J. G. (2012). Reflexive Management learning: An integrative review and a conceptual typology. Human Resource Development Review, 11(2), 227-253.

Crossan, M. M., Lane, H. and White, R. (1999). An organizational learning framework: From intuition to institution. Academy of Management Review, 24, 522-537.

Cullen, J. G. (2020). Varieties of responsible management learning: a review, typology and research agenda. Journal of Business Ethics, 162(4), 759-773.

Cunliffe, A. L. (2004). On becoming a critically reflexive practitioner. Journal of Management Education, 28, 407-426.

Cunliffe, A. L. (2016). "On Becoming a Critically Reflexive Practitioner" Redux: What Does It Mean to Be Reflexive? Journal of Management Education, 40(6), 740-746.

De Bakker, F. G. A., Rasche, A., \& Ponte, S. (2019). Multi-stakeholder initiatives on sustainability: A cross-disciplinary review and research agenda for business ethics. Business Ethics Quarterly, 29(3), 343-383.

*De Giacomo, M. R., Testa, F., Iraldo, F., \& Formentini, M. (2019). Does green public procurement lead to Life Cycle Costing (LCC) adoption? Journal of Purchasing and Supply Management, 25(3), 100500.

Dzhengiz, T., \& Niesten, E. (2020). Competences for environmental sustainability: A systematic review on the impact of absorptive capacity and capabilities. Journal of Business Ethics, 162(4), 881-906.

Edmondson, A., \& Moingeon, B. (1998). From organizational learning to the learning organization. Management Learning, 29(1), $5-20$. 
Edmondson, A. C., \& Nembhard, I. M. (2009). Product development and learning in project teams: The challenges are the benefits. Journal of Product Innovation Management, 26(2), 123-138.

Elliot, R., \& Timulak, L. (2005). A Handbook of Research Methods for Clinical and Health Psychology. Oxford: Oxford University Press.

*Ellström, P. E. (2010). Organizational learning. Learning and Cognition, $47-52$.

*Ely, A., Marin, A., Charli-joseph, L., Abrol, D., Apgar, M., Atela, J., Ayre, B., Byrne, R., Choudhary, B. K., Chengo, V., Cremaschi, A., Davis, R., Desai, P., Easkin, H., Kushwaha, P., Marshall, F., Mbeva, K., Ndege, N., Ochieng, C., ... Yang, L. (2020). Structured collaboration across a transformative knowledge network -learning across disciplines, cultures and contexts? Sustainability, 12, 1-20.

*Fisher, S., Dodman, D., Van Epp, M., \& Garside, B. (2018). The usability of climate information in sub-national planning in India, Kenya and Uganda: The role of social learning and intermediary organisations. Climatic Change, 151(2), 219-245.

Fortis, Z., Maon, F., Frooman, J., \& Reiner, G. (2018). Unknown knowns and known unknowns: Framing the role of organizational learning in corporate social responsibility development. International Journal of Management Reviews, 20(2), 277-300.

Freeth, R., \& Caniglia, G. (2020). Learning to collaborate while collaborating: Advancing interdisciplinary sustainability research. Sustainability Science, 15(1), 247-261.

Gast, I., Schildkamp, K., \& van der Veen, J. T. (2017). Team-based professional development interventions in higher education: A systematic review. Review of Educational Research, 87(4), 736-767.

*Halldórsson, Á., Gremyr, I., Winter, A., \& Taghahvi, N. (2018). Lean energy: Turning sustainable development into organizational renewal. Sustainability (switzerland), 10(12), 1-15.

*Hasanudin, A. I., Yuliansyah, Y., Said, J., Susilowati, C., \& Muafi. (2019). Management control system, corporate social responsibility, and firm performance. Entrepreneurship and Sustainability Issues, 6(3), 1354-1368.

Haugh, H. M., \& Talwar, A. (2010). How do corporations embed sustainability across the organization? Academy of Management Learning and Education, 9(3), 384-396.

*Heikkila, T., \& Gerlak, A. K. (2019). Working on learning: How the institutional rules of environmental governance matter. Journal of Environmental Planning and Management, 62(1), 106-123.

Hopwood, B., Mellor, M., \& O’Brien, G. (2005). Sustainable development: Mapping different approaches. Sustainable Development, $13,38-52$.

Hörisch, J., Freeman, R. E., \& Schaltegger, S. (2014). Applying stakeholder theory in sustainability management: Links, similarities, dissimilarities, and a conceptual framework. Organization and Environment, 27(4), 328-346.

*Howlett, M., Mukherjee, I., \& Koppenjan, J. (2017). Policy learning and policy networks in theory and practice: The role of policy brokers in the Indonesian biodiesel policy network. Policy and Society, 36(2), 233-250.

Hueting, R. (2010). Why environmental sustainability can most probably not be attained with growing production. Journal of Cleaner Production, 18(6), 525-530.

*Ingenbleek, P. T. M. and Dentoni, D. (2016). Learning from stakeholder pressure and embeddedness: The roles of absorptive capacity in the corporate social responsibility of Dutch agribusinesses. Sustainability (Switzerland), 8(10).

Intergovernmental Panel Climate Change. (2018). Global Warming of 1.5C. A Companion to Applied Ethics.

Jeong, S., Han, S. J., Lee, J., Sunalai, S., \& Yoon, S. W. (2018). Integrative literature review on informal learning: Antecedents, conceptualizations, and future directions. Human Resource Development Review, 17(2), 128-152.
Kemp, R., Loorbach, D., \& Rotmans, J. (2007). Transition management as a model for managing processes of co-evolution towards sustainable development. International Journal of Sustainable Development and World Ecology, 14(1), 78-91.

*Kiptot, E., \& Franzel, S. (2019). Stakeholder planning of the institutionalization of the volunteer farmer-trainer approach in dairy producer organizations in Kenya: Key steps and supporting mechanisms. International Journal of Agricultural Sustainability, 17(1), 18-33.

Koeslag-Kreunen, M., Van den Bossche, P., Hoven, M., Van der Klink, M., \& Gijselaers, W. (2018). When leadership powers team learning: A meta-analysis. Small Group Research, 49(4), 475-513.

Kozlowski, S., \& Chao, G. (2012). The dynamics of emergence: Cognition and cohesion in work teams. Managerial and Decision Economics, 33(June), 335-354.

Laasch, O. and Gherardi, S. (2019). Delineating and reconnecting responsible management, learning, and education: A research agenda through a social practices lens, Academy of Management Annual Conference. Boston.

Laasch, O., Moosmayer, D., Antonacopoulou, E., \& Schaltegger, S. (2020). Constellations of transdisciplinary practices: A map and research agenda for the responsible management learning field. Journal of Business Ethics, 162(4), 735-757.

Lam, A. (2000). Tacit knowledge, organizational learning and societal institutions: An integrated framework. Organization Studies, 21(3), 487-513.

*Lankester, A. J. (2013). Conceptual and operational understanding of learning for sustainability: A case study of the beef industry in north-eastern Australia. Journal of Environmental Management, 119, 182-193.

*Lee, T. (2019). Network comparison of socialization, learning and collaboration in the $\mathrm{C} 40$ cities climate group. Journal of Environmental Policy and Planning, 21(1), 104-115.

*Lee, T., \& van de Meene, S. (2012). Who teaches and who learns? Policy learning through the $\mathrm{C} 40$ cities climate network. Policy Sciences, 45(3), 199-220.

Linnenluecke, M. K., Russell, S. V., \& Griffiths, A. (2009). Subcultures and sustainability practices: The impact on understanding corporate sustainability. Business Strategy and the Environment, 18(7), 432-452.

*Lozano, R. (2014). Creativity and organizational learning as means to foster sustainability. Sustainable Development, 22(3), 205-216.

*Lukman, R., Krajnc, D., \& Glavič, P. (2009). Fostering collaboration between universities regarding regional sustainability initiatives - the University of Maribor. Journal of Cleaner Production, 17(12), 1143-1153.

*Lyra, M. G., Gomes, R. C., \& Pinto, M. M. (2017). Knowledge sharing relevance in social responsibility partnerships. Journal of Management Development, 36(1), 129-138.

*Madsen, H. M., Mikkelsen, P. S., \& Blok, A. (2019). Framing professional climate risk knowledge: Extreme weather events as drivers of adaptation innovation in Copenhagen Denmark. Environmental Science and Policy, 98(March), 30-38.

Mayring, P. (2014). Qualitative Content Analysis: Theoretical foundation, basic procedures and software solution. In A. BiknerAhsbahs, C. Knipping, \& N. Presmeg (Eds.), Approaches to Qualitative Research in Mathematics Education (pp. 365-380). Dordrecht: Springer.

McCright, A. M., \& Dunlap, R. E. (2010). Anti-reflexivity: The American conservative movement's success in undermining climate science and policy. Theory, Culture and Society, 27(2), 100-133.

*Molnar, E., \& Mulvihill, P. R. (2003). Sustainability-focused organizational learning: Recent experiences and new challenges. Journal of Environmental Planning and Management, 46(2), 167-176. 
Montiel, I., Jack, P., Raquel, G., \& Lopez, A. (2020). What on Earth Should Managers Learn About Corporate Sustainability? A Threshold Concept Approach. Journal of Business Ethics, 162(4), 857-880.

*Moyer, J. M., Sinclair, A. J., \& Diduck, A. P. (2014). Learning for sustainability among faith-based organizations in Kenya. Environmental Management, 54(2), 360-372.

Muff, K. (2012). Are business schools doing their job? Journal of Management Development, 31(7), 648-662.

*Müller, P., \& Slominsky, P. (2017). The politics of learning: Developing an emissions trading scheme in Australia. Global Environmental Politics, 17(3), 51-68.

Nyberg, D., \& Wright, C. (2016). Performative and political: Corporate constructions of climate change risk. Organization, 23(5), 617-638.

*Oelze, N., Hoejmose, S. U., Habisch, A., \& Millington, A. (2016). Sustainable development in supply chain management: The role of organizational learning for policy implementation. Business Strategy and the Environment, 25(4), 241-260.

*Osagie, E., Wesselink, R., Blok, V. and Mulder, M. (2020). Learning organization for corporate social responsibility implementation; unravelling the intricate relationship between organizational and operational learning organization characteristics. Organization and Environment, 1-24.

Pahl-Wostl, C. (2009). A conceptual framework for analysing adaptive capacity and multi-level learning processes in resource governance regimes. Global Environmental Change, 19(3), 354-365.

*Pallett, H., \& Chilvers, J. (2013). A decade of learning about publics, participation, and climate change: Institutionalising reflexivity? Environment and Planning A, 45(5), 1162-1183.

Petticrew, M., \& Roberts, H. (2006). Systematic reviews in the social sciences: A practical guide. Blackwell.

Probst, G., \& Büchel, B. (1997). Organizational Learning: The Competitive Advantage of the Future. Prentice Hall.

Prugsamatz, R. (2010). Factors that influence organization learning sustainability in non-profit organizations. Learning Organization, 17(3), 243-267.

Rashman, L., Withers, E., \& Hartley, J. (2009). Organizational learning and knowledge in public service organizations: A systematic review. International Journal of Management Reviews, 11(4), 463-494.

Raworth, K. (2014, August 11). Will these sustainable development goals get us into the doughnut? Kate Raworth Exploring Doughnut Economics. Retrieved from: https://www.kateraworth.com/ 2014/08/11/will-these-sustainable-development-goals-get-usinto-the-doughnut/

Raworth, K. (2017). Doughnut Economics: Seven Ways to Think Like a 21 st-Century Economist. Chelsea Green Publishing.

*Reddy, S. M. W., Torphy, K., Liu, Y., Chen, T., Masuda, Y. J., Fisher, J. R. B...and Montambault, J. R. (2019). How different forms of social capital created through project team assignments influence employee adoption of sustainability practices. Organization \& Environment, 1-31.

*Restrepo, M. J., Lelea, M. A., \& Kaufmann, B. A. (2018). Evaluating knowledge integration and co-production in a 2-year collaborative learning process with smallholder dairy farmer groups. Sustainability Science, 13(5), 1265-1286.

*Rietig, K., \& Perkins, R. (2018). Does learning matter for policy outcomes? The case of integrating climate finance into the EU budget. Journal of European Public Policy, 25(4), 487-505.

Rockström, J., Steffen, W., Noone, K., Persson, A., Chapin, F. S., Lambin, E. F. and Foley, J. A. (2009a). A safe operation space for humanity. Nature, 461(September).

Rockström, J., Steffen, W., Noone, K., Persson, Å., Chapin, F. S., Lambin, E. F., Lenton, T. M., Scheffer, M., Folke, C., Schellnhuber,
H., Nykvist, B., De Wit, C. A., Hughes, T., van der Leeuw, S., Rodhe, H., Sorlin, S., Snyder, P. K., Costanza, R., Svedin, U., ... Foley, J. (2009b). Planetary boundaries: Exploring the safe operating space for humanity. Ecology and Society, 14(2), 32.

Roulston, K., McClendon, V. J., Thomas, A., Tuff, R., Williams, G., $\&$ Healy, M. F. (2008). Developing reflective interviewers and reflexive researchers. Reflective Practice, 9(3), 231-243.

*Roux, D. J., Nel, J. L., Cundill, G., O'Farrell, P., \& Fabricius, C. (2017). Transdisciplinary research for systemic change: Who to learn with, what to learn about and how to learn. Sustainability Science, 12(5), 711-726.

Rumore, D., Schenk, T., \& Susskind, L. (2016). Role-play simulations for climate change adaptation education and engagement. Nature Climate Change, 6(8), 745-750.

*Ryan, A., Mitchell, I. K., \& Daskou, S. (2012). An interaction and networks approach to developing sustainable organizations. Journal of Organizational Change Management, 25(4), 578-594.

Salas-Zapata, W. A., \& Ortiz-Muñoz, S. M. (2019). Analysis of meanings of the concept of sustainability. Sustainable Development, 27(1), 153-161.

*Sánchez, L. E., \& Mitchell, R. (2017). Conceptualizing impact assessment as a learning process. Environmental Impact Assessment Review, 62, 195-204.

Schaefer, K., Corner, P. D., \& Kearins, K. (2015). Social, environmental and sustainable entrepreneurship research: What is needed for sustainability-as-flourishing? Organization and Environment, 28(4), 394-413.

Schaltegger, S., \& Wagner, M. (2011). Sustainable entrepreneurship and sustainability innovation: Categories and interactions. Business Strategy and the Environment, 20(4), 222-237.

Scheyvens, R., Banks, G., \& Hughes, E. (2016). The Private sector and the SDGs: The need to move beyond 'Business as Usual.' Sustainable Development, 24(6), 371-382.

*Scully-Russ, E. (2015). Green jobs career pathways: A qualitative study of the early startup experiences of two federally funded green jobs training partnerships in the United States. Advances in Developing Human Resources, 17(4), 473-488.

Senge, P. M., \& Carstedt, C. (2001). Innovating our way to the: Next industrial revolution. MIT Sloan Management Review, 42(2), 24-38.

Senge, P. M., \& Sterman, J. D. (1992). Systems thinking and organizational learning-acting locally and thinking globally in the organization of the future (Reprinted from European Journal Operational-Research, 1992). Transforming Organizations, 59, 353-371.

Sharma, S., \& Hart, S. L. (2014). Beyond "Saddle Bag" sustainability for business education. Organization and Environment, 27(1), $10-15$.

Sharma, S., \& Ruud, A. (2003). On the path to sustainability: Integrating social dimensions into the research and practice of environmental management. Business Strategy and the Environment, 12(4), 205-214.

Sharp, M., \& Threadgold, S. (2020). Defiance labour and reflexive complicity: Illusio and gendered marginalisation in DIY punk scenes. Sociological Review, 68(3), 606-622.

Short, J. C. (2009). The art of writing a review article. Journal of Management, 35(6), 1312-1317.

Shrivastava, P., Ivanaj, S. and Persson, S. (2013). Transdisciplinary study of sustainable enterprise. Business Strategy and the Environment, 22, 230-244.

Siebenhüner, B., \& Arnold, M. (2007). Organizational learning to manage sustainable development. Business Strategy and the Environment, 16(5), 339-353.

Snowden, D. J. and Boone, M. E. (2007). A Leader's Framework for Decision Making - Harvard Business Review. Harvard Business Review, 1-8. 
*Sol, J., van der Wal, M. M., Beers, P. J., \& Wals, A. E. J. (2018). Reframing the future: The role of reflexivity in governance networks in sustainability transitions. Environmental Education Research, 24(9), 1383-1405.

*Stagl, S. (2007). Theoretical foundations of learning processes for sustainable development. International Journal of Sustainable Development and World Ecology, 14(1), 52-62.

*Storbjörk, S. (2010). "It takes more to get a ship to change course": Barriers for organizational learning and local climate adaptation in Sweden. Journal of Environmental Policy and Planning, 12(3), 235-254.

*Stubbs, M., \& Lemon, M. (2001). Learning to network and networking to learn: Facilitating the process of adaptive management in a local response to the UK's national air quality strategy. Environmental Management, 27(3), 321-334.

Teare, R. (1997). Enabling organizational learning. International Journal of Contemporary Hospitality Management, 9(7), 315.

Tosey, P., Visser, M., \& Saunders, M. N. K. (2012). The origins and conceptualizations of "triple-loop" learning: A critical review. Management Learning, 43(3), 291-307.

*Totin, E., Butler, J. R., Sidibé, A., Partey, S., Thornton, P. K., \& Tabo, R. (2018). Can scenario planning catalyse transformational change? Evaluating a climate change policy case study in Mali. Futures, 96, 44-56.

United Nations. (2016). Transforming our World: The 2030 Agenda for Sustainable Development. In Arsenic Research and Global Sustainability - Proceedings of the 6th International Congress on Arsenic in the Environment, AS 2016.

United Nations Educational, Scientific and Cultural Organization. (2019, May 29). Sustainable Development. Retrieved from: https://en.unesco.org/themes/education-sustainable-devel opment/what-is-esd/sd.

United Nations. (2019). The Sustainable Development Goals Report 2019.

*van de Kerkhof, M., \& Wieczorek, A. (2005). Learning and stakeholder participation in transition processes towards sustainability: Methodological considerations. Technological Forecasting and Social Change, 72(6), 733-747.

Web of Science Group. (2019, July 12). Web of Science platform: Web of Science: Summary of Coverage. Retrieved from: https://clari vate.libguides.com/webofscienceplatform/coverage.

*Weissbrod, I., \& Bocken, N. M. P. (2017). Developing sustainable business experimentation capability-A case study. Journal of Cleaner Production, 142, 2663-2676.
*Wicki, S., \& Hansen, E. G. (2019). Green technology innovation: Anatomy of exploration processes from a learning perspective. Business Strategy and the Environment, 28, 970-988.

*Willems, J. J., Busscher, T., van den Brink, M., \& Arts, J. (2018). Anticipating water infrastructure renewal: A framing perspective on organizational learning in public agencies. Environment and Planning c: Politics and Space, 36(6), 1088-1108.

Williams, A., Kennedy, S., Philipp, F., \& Whiteman, G. (2017). Systems thinking: A review of sustainability management research. Journal of Cleaner Production, 148, 866-881.

*Wossen, T., Berger, T., Mequaninte, T., \& Alamirew, B. (2013). Social network effects on the adoption of sustainable natural resource management practices in Ethiopia. International Journal of Sustainable Development and World Ecology, 20(6), 477-483.

Wright, C., \& Nyberg, D. (2017). An inconvenient truth: How organizations translate climate change into business as usual. Academy of Management Journal, 60(5), 1633-1661.

*Yumagulova, L., \& Vertinsky, I. (2019). Moving beyond engineering supremacy: Knowledge systems for urban resilience in Canada's Metro Vancouver region. Environmental Science and Policy, 100, $66-73$.

*Zeimers, G., Anagnostopoulos, C., Zintz, T., \& Willem, A. (2019). Organisational learning for corporate social responsibility in sport organisations. European Sport Management Quarterly, 19(1), 80-101.

*Zhang, F., Welch, E. W., \& Miao, Q. (2018). Public organization adaptation to extreme events: Mediating role of risk perception. Journal of Public Administration Research and Theory, 28(3), 371-387.

*Zhao, Z., Meng, F., He, Y., \& Gu, Z. (2019). The influence of corporate social responsibility on competitive advantage with multiple mediations from social capital and dynamic capabilities. Sustainability (Switzerland), 11(1), 218.

*Zwetsloot, G. I. J. M. (2003). From management systems to corporate social responsibility. Journal of Business Ethics, 44(2-3), 201-207.

Publisher's Note Springer Nature remains neutral with regard to jurisdictional claims in published maps and institutional affiliations. 